\title{
Succession in Rocky Intertidal Benthic Communities in Areas with Different Pollution Levels at Guanabara Bay (RJ-Brazil)
}

\author{
André Breves-Ramos ${ }^{*}$, Helena Passeri Lavrado, Andrea de Oliveira Ribeiro Junqueira and \\ Sérgio Henrique Gonçalves da Silva \\ Universidade Federal do Rio de Janeiro; Instituto de Biologia; Departamento de Biologia Marinha; CCS; Bloco A; \\ Laboratório de Benthos; Sala 089; Rua Brigadeiro Trompowski; 21941-590; abr@biologia.ufrj.br; Rio de Janeiro - \\ RJ - Brasil
}

\begin{abstract}
The aim of this study was to describe and compare the succession of intertidal benthic communities in two areas at Guanabara Bay, RJ, Brazil: Urca, an area submitted to moderated organic pollution and Catalão, an extremely polluted area. Three transects in each area were scraped one month before the beginning of this study in order to evaluate the recruitment (recruitment-treatments). Three other transects were monitored without manipulation (monitoring treatments). Species composition and relative abundance were evaluated monthly between September and December, 2000. A total of 26 species was found at Urca and 13 at Catalão. The percent cover of the most abundant organisms was not similar between treatments at Urca after four months, while in Catalão, the similarity was $72 \%$ in the second month. The faster community development and recovery at the most polluted area was probably related to the existence of simple and resilient communities in more impacted areas.
\end{abstract}

Key words: Benthic communities, succession, rocky intertidal zone, Guanabara Bay

\section{INTRODUCTION}

Many studies about the succession process in the marine environment have been carried out using benthic communities of hard substrates (Machado et al., 1992; McCook and Chapman, 1997; Benedetti-Cecchi, 2000). Some authors (WHOI, 1952; Souza, 1979; Benedetti-Cecchi, 2000) have observed an arranged succession in which the pioneering organisms had an influence on subsequent species. However, other authors did not believe that benthic community development could be predictable (Gray and Christie, 1983; Currie and Parry, 1999). Usually, the development of a new intertidal community follows a temporal sequence of taxa. The great problem is the uncertainty as to whether this sequence of species during the community development is due to seasonal cycles or if it is a real succession (Scheer, 1945).

Eutrophication may increase and speed up the development of fouling communities since opportunistic organisms (i.e., with a great reproductive capacity and rapid growth rate) are favoured in eutrophicated habitats (Murray and Littler, 1978).

Marine organisms could be used as pollution indicators. Many studies have evaluated the

\footnotetext{
* Author for correspondence
} 
relation between environmental variables and species (Necchi Junior et al., 1994; Carballo et al., 1996; Naranjo et al., 1996). Temperature, salinity, turbidity and the pollution level influence the structure of a benthic community (Holland et al., 1984; Omena et al., 1993; González-Oreja and Saiz-Salinas, 1998; Saiz-Salinas and UrkiagaAlberdi, 1999). Organic pollution, one of the greatest threats to coastal environments, affects the development of benthic communities directly and indirectly. In higher levels, pollution causes a decrease of biomass and diversity and favours opportunistic species (Murray and Littler, 1978; Diez et al., 1999).

The aim of the present work was to describe and compare the succession of intertidal benthic communities in two areas with different levels of eutrophication in Guanabara Bay, RJ.

\section{STUDY AREA}

Guanabara Bay is situated in the State of Rio de

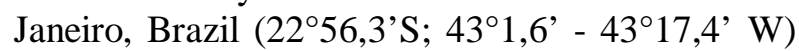
and has an area of $380 \mathrm{~km}^{2}$. It corresponds to a semi-enclosed coastal environment which is connected to the sea by an access $1.6 \mathrm{~km}$ wide (Kjerfve et al., 1997). The Bay is in a fast process of degradation. Its water quality is not uniform and some gradients can be observed in many of the hydrobiological characteristics, such as higher salinities towards the mouth and a increase of pollution levels towards the inner regions. The present work took place at two areas of Guanabara Bay (Fig. 1):

1) Urca - an artificial rocky substrate near the mouth of the Bay in a moderately polluted area. There is an intense flow of water in this area which decreases the pollution. At this site, the salinity of the surface water (around 32) is higher than in inner areas of the Bay due to its proximity to coastal waters with high salinity.

2) Catalão - natural rocky shore in the west part of the Bay at Fundão Island. This region presents an advanced stage of deterioration with a high level of eutrophication (Kjerfve et al., 1997). This area is very silty with a low water circulation. The lower salinity in this region, usually 27 , is due to the continuous inflows of fresh water caused by the large drainage basin that exists around this area (Kjerfve et al., 1997).

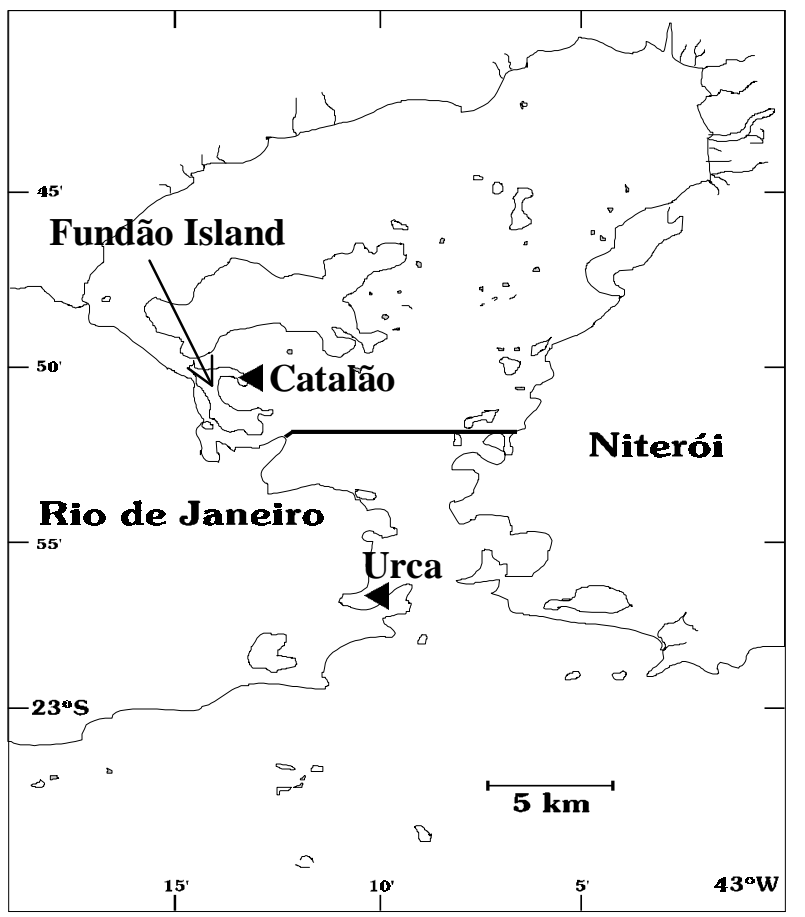

Figure 1 - Map of Guanabara Bay with the study areas.

\section{MATERIALS AND METHODS}

\section{Field Work}

The specific composition and relative abundance of intertidal benthic organisms at Urca and Catalão were monitored monthly from September to December, 2000. In each area, six fixed vertical transects, randomly chosen, were established. Three transects were scraped with a brush one month before the beginning of this study in order to withdraw all the organisms. After that, the abundance of recolonizing organisms was monitored (Recruitment treatment). In the other three transects, the established community was maintained and the abundance of organisms was also monitored (Monitoring treatment).

In each transect, four contiguous quadrats of 400 $\mathrm{cm}^{2}(20 \times 20 \mathrm{~cm})$ were sampled. Only the outer layer of the community (canopy cover) was considered. In order to evaluate the relative abundance of the organisms, the non-destructive estimation method of percentage cover described by Sutherland (1974) was used. During periods of lower tides, extra quadrats in the low-intertidal zone were sampled. However, these data were not considered in the quantitative analysis because they were sparsely obtained. The organisms that could not be 
identified in situ were collected and identified in the laboratory.

\section{Data Analysis}

The relative abundance of conspicuous organisms was obtained using the mean percentage cover found in the quadrats of the main zones where they occurred in the substrate. The relative abundance of the dominant groups (Chlorophyta, Balanidae and Chthamalidae) were compared between treatments and areas using a two-way ANOVA and $a$ posteriori Tukey test with $\alpha=0.05$ (Zar, 1996). Data were transformed (asin Vproportion) if necessary.

To verify the similarities in species composition and relative abundances of the main groups between the two treatments, cluster analysis were performed using Bray Curtis and Jaccard indices with UPGMA aggregation algorithm using MVSP (MultiVariate Statistical Package)/Software version 3.1 (http://www.kovcorp.com).

\section{RESULTS}

\section{Community composition}

A total of 21 taxa of marine invertebrates and eight taxa of algae were found in this study. At Urca, 18 taxa of marine invertebrates and eight of algae were found, whereas at Catalão, 12 taxa of invertebrates and only one of algae were registered. In both areas, taxa in the low-intertidal zones were observed. At Urca, 13 taxa of invertebrates were also identified in this zone - the gastropod Stramonita haemastoma, the bivalve Perna perna, the barnacle Megabalanus coccopoma, the ascidians Botrylloides nigrum, Styela plicata and Symplegma sp., the bryozoans Bugula turrita, B. neritina, Zoobotryum pellucidum and Schizoporella sp. and sponges of the genus Leucilla and of the order Haplosclerida. At Catalão, the anemone Aiptsia pallida and the chlorophyte Enteromorpha lingulata were found in the low-intertidal zone.

At Urca some species occurred only in the recruitment treatment. In this area, other species were found exclusively in the monitoring treatment. At Catalão, some were found only in the monitoring treatments but no species were found exclusively in the recruitment treatment (Tables 1-4). In the final month of this study (December), most of the species at Urca and at Catalão were observed in both treatments (Tables 1-4). The four months of this study were enough for the communities of the recruitment treatment become similar to the communities in the monitoring treatment regarding their species composition.

Table 1 - Marine invertebrates occurrence at Urca, in September (S), October (O), November (N) and December (D) of 2000, in monitoring (M) and recruitment (R) treatments. $\mathrm{x}=$ present in the quadrats of the transects. $\mathrm{O}=$ present in the lower portion of the transects.

\begin{tabular}{|c|c|c|c|c|c|c|c|c|}
\hline Taxa / Months & SM & SR & $\mathrm{OM}$ & OR & NM & NR & DM & DR \\
\hline \multicolumn{9}{|l|}{ Porifera } \\
\hline Haplosclerida & o & & & & & & & \\
\hline Hymeniacidon heliophila & $\mathrm{x}$ & & $\mathrm{x}$ & $\mathrm{x}$ & $\mathrm{x}$ & $\mathrm{x}$ & $\mathrm{x}$ & $\mathrm{x}$ \\
\hline Leucilla sp. & $\mathrm{o}$ & & o & & & & & \\
\hline
\end{tabular}

\section{Cnidaria - Hydrozoa}

Obelia dichotoma $\mathrm{x}$

\begin{tabular}{|c|c|c|c|c|c|c|c|c|}
\hline \multicolumn{9}{|l|}{ Cnidaria - Anthozoa } \\
\hline Aiptsia pallida & & & & & & $\mathrm{x}$ & & \\
\hline Bunodosoma caissarum & $\mathrm{x}$ & & $\mathrm{x}$ & & o & o & $\mathrm{x}$ & \\
\hline \multicolumn{9}{|l|}{ Mollusca - Gastropoda } \\
\hline Collisella subrugosa & $\mathrm{x}$ & $\mathrm{x}$ & $\mathrm{x}$ & $\mathrm{x}$ & $\mathrm{x}$ & $\mathrm{x}$ & $\mathrm{x}$ & $\mathrm{x}$ \\
\hline Nodilittorina ziczac & $\mathrm{x}$ & & & & $\mathrm{x}$ & & & \\
\hline Stramonita haemastoma & & & o & & & & & \\
\hline Petaloconchus sp. & $\mathrm{x}$ & & $\mathrm{x}$ & & $\mathrm{x}$ & & $\mathrm{x}$ & $\mathrm{x}$ \\
\hline \multicolumn{9}{|l|}{ Mollusca - Bivalvia } \\
\hline Ostreidae & & & o & & $\mathrm{x}$ & & & \\
\hline Perna perna & o & & o & & & & & \\
\hline
\end{tabular}




\begin{tabular}{|c|c|c|c|c|c|c|c|c|}
\hline \multicolumn{9}{|l|}{ Cont. Table 1} \\
\hline \multicolumn{9}{|l|}{ Polychaeta } \\
\hline \multirow{2}{*}{$\begin{array}{l}\text { Hydroides plateni } \\
\text { Polydora websteri }\end{array}$} & $\mathrm{x}$ & $\mathrm{x}$ & $\mathrm{x}$ & \multirow[t]{2}{*}{$\mathrm{x}$} & \multirow{2}{*}{$\begin{array}{l}\mathrm{X} \\
\mathrm{X} \\
\end{array}$} & \multirow{2}{*}{$\begin{array}{l}\mathrm{X} \\
\mathrm{X} \\
\end{array}$} & \multirow{2}{*}{$\begin{array}{l}\mathrm{X} \\
\mathrm{X} \\
\end{array}$} & \multirow{2}{*}{$\begin{array}{l}\mathrm{X} \\
\mathrm{X}\end{array}$} \\
\hline & $\mathrm{x}$ & $\mathrm{x}$ & $\mathrm{x}$ & & & & & \\
\hline \multicolumn{9}{|c|}{ Crustacea - Cirripedia - Balanidae } \\
\hline Balanus amphitrite & $\mathrm{x}$ & & $\mathrm{x}$ & $\mathrm{x}$ & $\mathrm{x}$ & & $\mathrm{x}$ & $\mathrm{x}$ \\
\hline Balanus eburneus & & & & & o & & $\mathrm{x}$ & \\
\hline Megabalanus coccopoma & & & o & & & & & \\
\hline \multicolumn{9}{|c|}{ Crustacea - Cirripedia - Chthamalidae } \\
\hline Chthamalus bisinuatus & $\mathrm{x}$ & & $\mathrm{x}$ & & $\mathrm{x}$ & & $\mathrm{x}$ & $\mathrm{x}$ \\
\hline \multicolumn{9}{|c|}{ Crustacea - Cirripedia - Tetraclitidae } \\
\hline Tetraclita stalactifera & $\mathrm{x}$ & & $\mathrm{x}$ & & $\mathrm{x}$ & & $\mathrm{X}$ & \\
\hline Taxa / Months & SM & SR & $\mathrm{OM}$ & OR & NM & NR & $\mathrm{DM}$ & DR \\
\hline \multicolumn{9}{|l|}{ Ascidiacea } \\
\hline Botrylloides giganteum & o & & o & & $\mathrm{x}$ & & & \\
\hline Botrylloides nigrum & & & o & & & & & \\
\hline Diplosoma listerianum & & & & & & & & $\mathrm{x}$ \\
\hline Styela plicata & o & & & o & & & & \\
\hline Symplegma sp. & 0 & & & & & & & \\
\hline \multicolumn{9}{|l|}{ Echinoidea } \\
\hline Arbacia lixula & & & 0 & & & & & \\
\hline \multicolumn{9}{|l|}{ Bryozoa (encrusting) } \\
\hline Alcyonidium sp. & $\mathrm{x}$ & o & $\mathrm{x}$ & $\mathrm{x}$ & $\mathrm{x}$ & $\mathrm{x}$ & $\mathrm{x}$ & $\mathrm{x}$ \\
\hline Schizoporella sp. & 0 & & & & & & & \\
\hline \multicolumn{9}{|l|}{ Bryozoa (arborescent) } \\
\hline Bowerbankia caudata & & & & & & & & $\mathrm{x}$ \\
\hline Bugula neritina & o & & & & & & & \\
\hline Bugula turrita & & & o & & & & & \\
\hline Zoobotryon pellucidum & & & & & & $\mathrm{o}$ & & \\
\hline
\end{tabular}

Table 2 - Algae occurrence at Urca, in September (S), October (O), November (N) and December (D) of 2000 in monitoring $(\mathrm{M})$ and recruitment $(\mathrm{R})$ treatments. $\mathrm{x}=$ present between the quadrats of the transects. $\mathrm{o}=$ present in the lower portion of the transects

\begin{tabular}{|c|c|c|c|c|c|c|c|c|}
\hline Taxa / Months & $\mathrm{SM}$ & SR & $\mathrm{OM}$ & OR & NM & NR & $\mathrm{DM}$ & $\overline{\mathrm{DR}}$ \\
\hline \multicolumn{9}{|l|}{ Cyanophyta } \\
\hline Cyanophycea & & & $\mathrm{x}$ & $\mathrm{x}$ & & & & \\
\hline \multicolumn{9}{|l|}{ Rhodophyta } \\
\hline Bostrychia radicans & & & $\mathrm{x}$ & & & & & \\
\hline Centroceras clavulatum & & & & & $\mathrm{x}$ & o & & \\
\hline Chondracanthus teedii & $\mathrm{x}$ & $\mathrm{x}$ & $\mathrm{x}$ & $\mathrm{x}$ & $\mathrm{x}$ & & $\mathrm{x}$ & $\mathrm{x}$ \\
\hline Gelidium pusillum & $\mathrm{x}$ & $\mathrm{x}$ & & & & & & \\
\hline Gymnogongrus griffithsiae & & & & & $\mathrm{x}$ & $\mathrm{x}$ & & \\
\hline \multicolumn{9}{|l|}{ Chlorophyta } \\
\hline Cladophora sp. & $\mathrm{x}$ & $\mathrm{x}$ & o & & $\mathrm{x}$ & $\mathrm{x}$ & $\mathrm{x}$ & $\mathrm{x}$ \\
\hline Ulva spp. & $\mathrm{x}$ & $\mathrm{x}$ & $\mathrm{x}$ & $\mathrm{x}$ & $\mathrm{x}$ & $\mathrm{x}$ & $\mathrm{x}$ & $\mathrm{x}$ \\
\hline
\end{tabular}


Table 3 - Marine invertebrates occurrence at Catalão, in September (S), October (O), November (N) and December (D) of 2000, in monitoring (M) and recruitment (R) treatments. $\mathrm{x}=$ present in the quadrats of the transects. $\mathrm{o}=$ present in the lower portion of the transects

\begin{tabular}{|c|c|c|c|c|c|c|c|c|}
\hline Taxa / Months & SM & SR & $\mathrm{OM}$ & OR & NM & NR & $\mathrm{DM}$ & DR \\
\hline \multicolumn{9}{|l|}{ Cnidaria - Hydrozoa } \\
\hline Obelia dichotoma & $\mathrm{x}$ & $\mathrm{x}$ & $\mathrm{x}$ & $\mathrm{x}$ & $\mathrm{x}$ & $\mathrm{x}$ & $\mathrm{x}$ & $\mathrm{x}$ \\
\hline \multicolumn{9}{|l|}{ Cnidaria - Anthozoa } \\
\hline Aiptsia pallida & & & o & $\mathrm{o}$ & 0 & & & o \\
\hline Haliplanella lineata & $\mathrm{x}$ & & $\mathrm{x}$ & 0 & $\mathrm{x}$ & $\mathrm{x}$ & & \\
\hline Tricnidactis errans & $\mathrm{x}$ & $\mathrm{x}$ & $\mathrm{x}$ & 0 & $\mathrm{x}$ & $\mathrm{x}$ & $\mathrm{x}$ & $\mathrm{x}$ \\
\hline \multicolumn{9}{|l|}{ Mollusca - Gastropoda } \\
\hline Colisella subrugosa & & & & & & & $\mathrm{x}$ & \\
\hline Nodlittorina ziczac & & & $\mathrm{x}$ & & & & & \\
\hline \multicolumn{9}{|l|}{ Polychaeta } \\
\hline Hydroides plateni & & & & & $\mathrm{x}$ & $\mathrm{x}$ & $\mathrm{x}$ & $\mathrm{x}$ \\
\hline Polydora websteri & $\mathrm{x}$ & $\mathrm{x}$ & $\mathrm{x}$ & $\mathrm{x}$ & $\mathrm{x}$ & $\mathrm{x}$ & $\mathrm{x}$ & $\mathrm{x}$ \\
\hline Taxa / Months & SM & SR & $\mathrm{OM}$ & OR & NM & NR & DM & DR \\
\hline \multicolumn{9}{|c|}{ Crustacea - Cirripedia - Balanidae } \\
\hline Balanus amphitrite & $\mathrm{x}$ & $\mathrm{x}$ & $\mathrm{x}$ & $\mathrm{x}$ & $\mathrm{x}$ & $\mathrm{x}$ & $\mathrm{x}$ & $\mathrm{x}$ \\
\hline Balanus eburneus & $\mathrm{x}$ & & $\mathrm{x}$ & $\mathrm{x}$ & 0 & $\mathrm{x}$ & $\mathrm{x}$ & $\mathrm{x}$ \\
\hline \multicolumn{9}{|c|}{ Crustacea - Cirripedia - Chthamalidae } \\
\hline Chthamalus bisinuatus & $\mathrm{x}$ & & $\mathrm{x}$ & & $\mathrm{X}$ & & $\mathrm{x}$ & \\
\hline Euraphia rhizophorae & & & $\mathrm{x}$ & & & & & \\
\hline \multicolumn{9}{|l|}{ Bryozoa (encrusting) } \\
\hline Alcyonidium sp. & $\mathrm{x}$ & & & $\mathrm{x}$ & & & & \\
\hline
\end{tabular}

Table 4 - Algae occurrence at Catalão, in September (S), October (O), November (N) and December (D) of 2000 in monitoring $(\mathrm{M})$ and recruitment $(\mathrm{R})$ treatments. $\mathrm{x}=$ present between the quadrats of the transects. $\mathrm{o}=$ present in the lower portion of the transects.

\begin{tabular}{lcccccccc}
\hline Taxa / Months & SM & SR & OM & OR & NM & NR & DM & DR \\
\hline Chlorophyta & & & & & & & & \\
\hline Enteromorpha lingulata & & & o & o & & & & \\
Ulva spp. & x & x & x & x & x & x & x & x \\
\hline
\end{tabular}

At the beginning of this study, the total number of taxa in the monitoring treatment at Urca was very different from the recruitment. In December, the total number of taxa increased in the recruitment treatment and both monitoring and recruitment became similar (Fig. 2). At Catalão, the total number of taxa at the monitoring was greater than at the recruitment in the first two months, becoming equal in the third one. In the last month, the number of taxa at the monitoring and recruitment were similar (Fig. 3).

\section{Abundance of the Main Groups}

Chlorophyta was dominant in the four months of study at Urca, both in monitoring and recruitment treatments. Chthamalidae and Rhodophyta were also frequent in the monitoring treatment, while Polychaeta, Bryozoa (encrusting) and Rhodophyta were abundant in the recruitment treatment in almost all months (Figs. 4 and 5). At Catalão, the dominant barnacle family during all the period of this study (four months) was Balanidae in both treatments. Polychaeta, Hydrozoa, Anthozoa and Chlorophyta groups also ocurred in almost all monitoring months. These groups also had a high percentage cover in the recruitment treatment, except Anthozoa (Fig. 6). At Catalão, Chthamalidae presented a low percentage cover in monitoring and did not occur in the recruitment treatment (Figs. 6 and 7). The Mollusca group was not included in this analysis due to its low 
abundance in this area, although it frequently occured at Urca.

Chlorophyta, Balanidae and Chthamalidae presented a percentage cover significantly different in all months and at both sites. However, Chlorophyta did not have a significant difference between monitoring and recruitment treatments, in both areas. Balanidae presented a significant difference between the treatments only in the first month at Catalão. The group of Chthamalidae, however, presented a significant difference between the treatments only at Urca (Table 5).

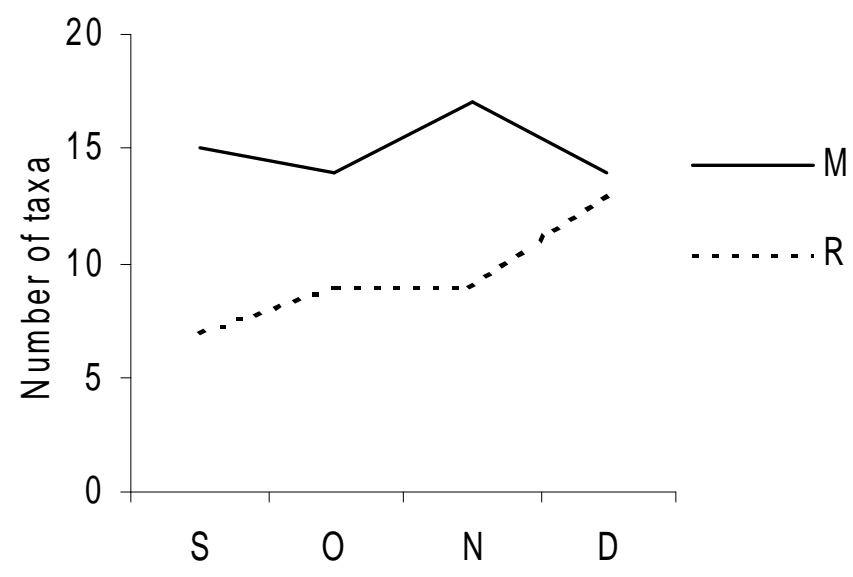

Figure 2 - Total number of taxa at Urca at the monitoring $(M)$ and recruitment $(R)$ treatments, in September (S), October (O), November (N) and December (D) of 2000.

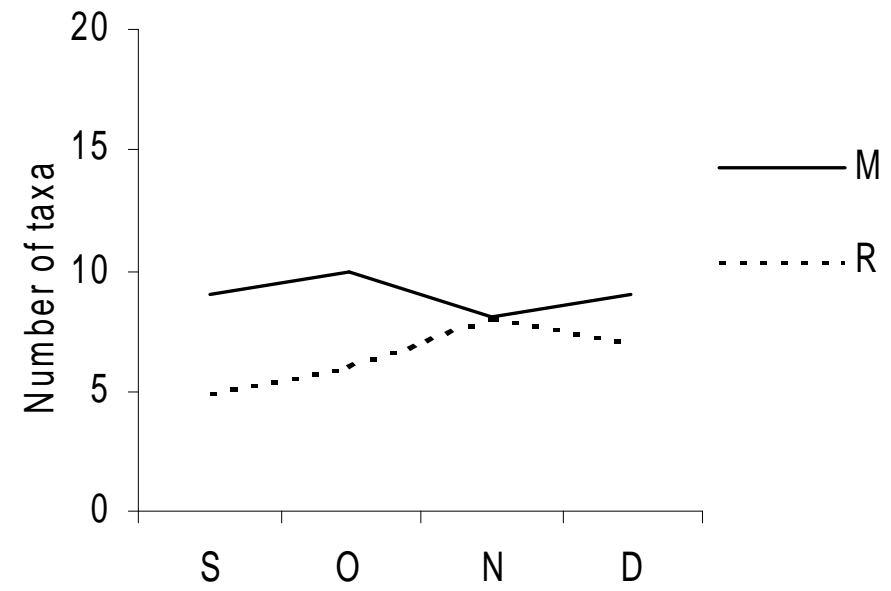

Figure 3 - Total number of taxa at Catalão at the monitoring $(\mathrm{M})$ and recruitment $(\mathrm{R})$ treatments, in September (S), October (O), November (N) and December (D) of 2000. 
Table 5 - Results of ANOVA of the groups Chlorophyta, Balanidae and Chthamalidae in September (S), October (O), November (N) and December (D) of 2000, between areas (Urca and Catalão), treatments (monitoring and recruitment $)$ and interation $(\mathrm{M}=$ month; $\mathrm{DF}=$ degrees of freedom; *significant values- $p<0.05)$.

\begin{tabular}{|c|c|c|c|c|c|}
\hline Groups & $\mathbf{M}$ & Source & DF & $F$ & $P$ \\
\hline \multirow[t]{12}{*}{ Chlorophyta } & \multirow[t]{3}{*}{$\mathrm{S}$} & Area & 1 & 34.440 & $0.000^{*}$ \\
\hline & & Treatment & 1 & 1.720 & 0.226 \\
\hline & & $\mathrm{A} \times \mathrm{T}$ & 1 & 4.498 & 0.067 \\
\hline & \multirow[t]{3}{*}{$\mathrm{O}$} & Area & 1 & 15.670 & $0.004 *$ \\
\hline & & Treatment & 1 & 0.377 & 0.556 \\
\hline & & $\mathrm{Ax} \mathrm{T}$ & 1 & 0.474 & 0.511 \\
\hline & \multirow[t]{3}{*}{$\mathrm{N}$} & Area & 1 & 165.600 & $0.000^{*}$ \\
\hline & & Treatment & 1 & 1.737 & 0.224 \\
\hline & & $\mathrm{A} \times \mathrm{T}$ & 1 & 1.418 & 0.268 \\
\hline & \multirow[t]{3}{*}{$\mathrm{D}$} & Area & 1 & 45.480 & $0.000^{*}$ \\
\hline & & Treatment & 1 & 0.109 & 0.750 \\
\hline & & $\mathrm{A} \times \mathrm{T}$ & 1 & 0.155 & 0.704 \\
\hline \multirow[t]{12}{*}{ Balanidae } & \multirow[t]{3}{*}{$\mathrm{S}$} & Area & 1 & 33.810 & $0.000^{*}$ \\
\hline & & Treatment & 1 & 55.580 & $0.000^{*}$ \\
\hline & & $\mathrm{A} \times \mathrm{T}$ & 1 & 25.820 & $0.001 *$ \\
\hline & \multirow[t]{3}{*}{$\mathrm{O}$} & Area & 1 & 7.098 & $0.029 *$ \\
\hline & & Treatment & 1 & 3.575 & 0.095 \\
\hline & & $\mathrm{A} \times \mathrm{T}$ & 1 & 0.470 & 0.512 \\
\hline & \multirow[t]{3}{*}{$\mathrm{N}$} & Área & 1 & 11.990 & $0.008^{*}$ \\
\hline & & Treatment & 1 & 2.025 & 0.193 \\
\hline & & $\mathrm{A} \times \mathrm{T}$ & 1 & 0.002 & 0.964 \\
\hline & \multirow[t]{3}{*}{$\mathrm{D}$} & Área & 1 & 14.270 & $0.005^{*}$ \\
\hline & & Treatment & 1 & 4.530 & 0.066 \\
\hline & & $\mathrm{A} \times \mathrm{T}$ & 1 & 0.872 & 0.378 \\
\hline \multirow{12}{*}{ Chthamalidae } & \multirow[t]{3}{*}{$\mathrm{S}$} & Area & 1 & 6.173 & $0.038 *$ \\
\hline & & Treatment & 1 & 17.450 & $0.003 *$ \\
\hline & & $\mathrm{A} \times \mathrm{T}$ & 1 & 6.173 & $0.038 *$ \\
\hline & \multirow[t]{3}{*}{$\mathrm{O}$} & Area & 1 & 8.822 & $0.018^{*}$ \\
\hline & & Treatment & 1 & 21.290 & $0.002 *$ \\
\hline & & $\mathrm{A} \times \mathrm{T}$ & 1 & 8.822 & $0.018^{*}$ \\
\hline & \multirow[t]{3}{*}{$\mathrm{N}$} & Área & 1 & 10.300 & $0.012 *$ \\
\hline & & Treatment & 1 & 21.500 & $0.002 *$ \\
\hline & & $\mathrm{A} \times \mathrm{T}$ & 1 & 10.300 & $0.012 *$ \\
\hline & \multirow[t]{3}{*}{$\mathrm{D}$} & Área & 1 & 28.490 & $0.001 *$ \\
\hline & & Treatment & 1 & 31.720 & $0.001 *$ \\
\hline & & $\mathrm{A} \times \mathrm{T}$ & 1 & 21.430 & $0.002 *$ \\
\hline
\end{tabular}




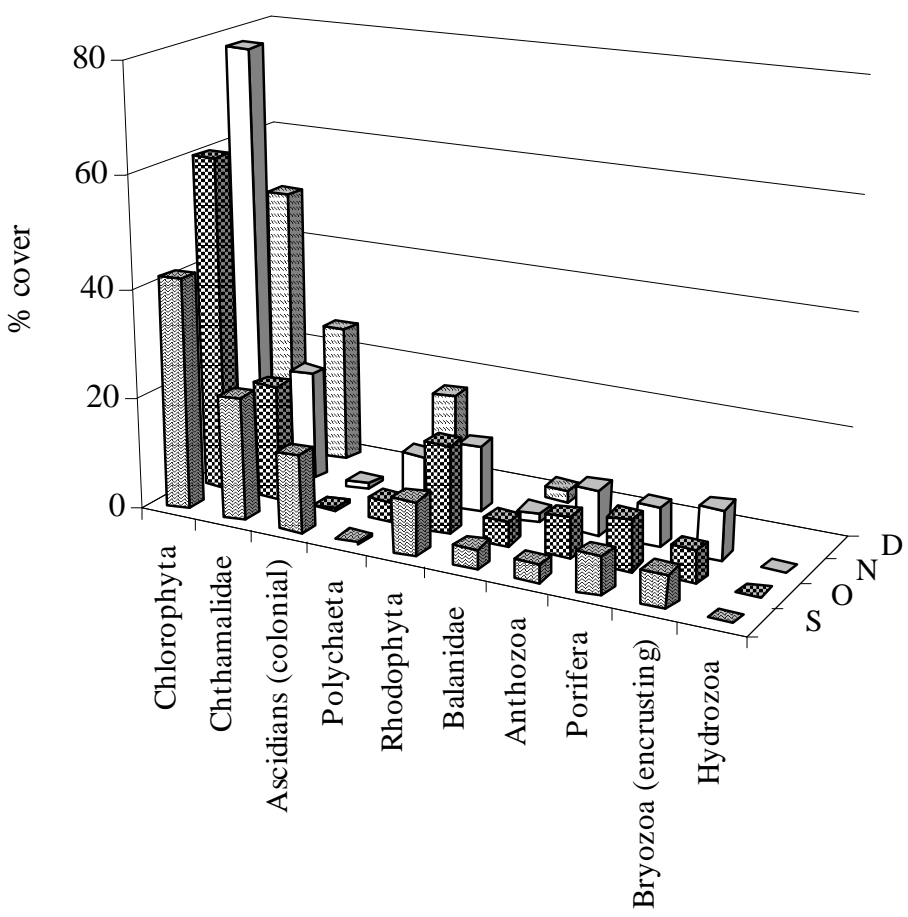

Figure 4 - Percent cover of the main groups in the monitoring treatment at Urca, in September (S), October (O), November (N) and December (D) of 2000.

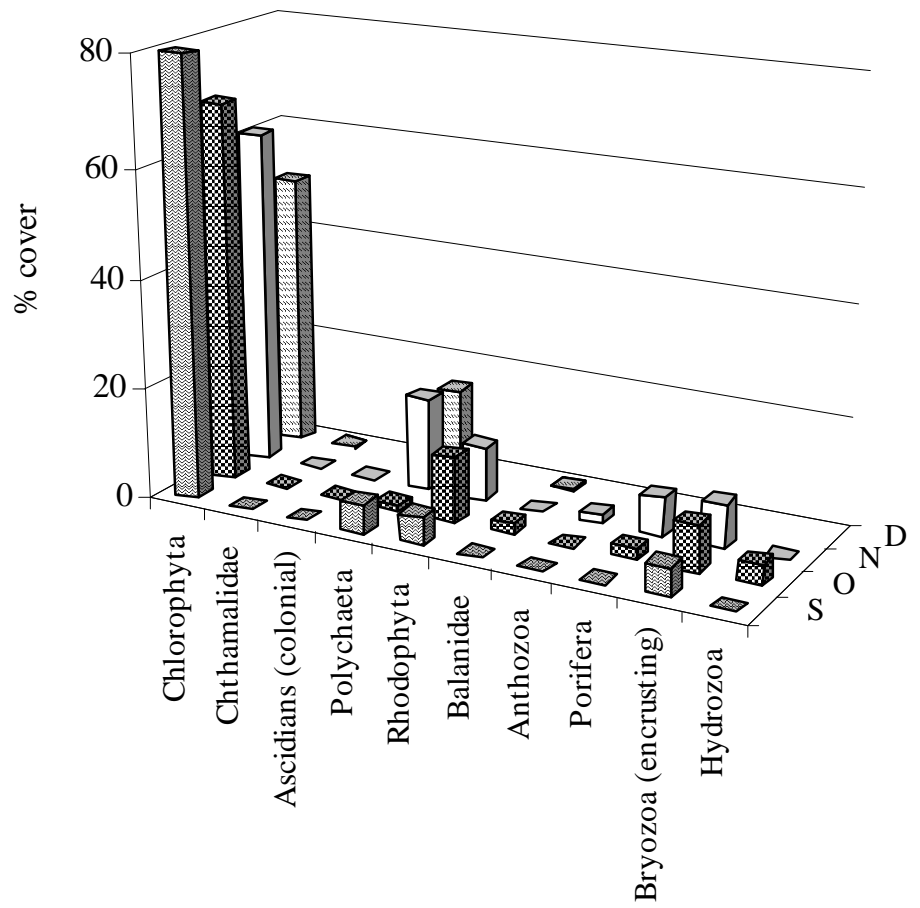

Figure 5 - Percent cover of the main groups in the recruitment treatment at Urca, in September (S), October (O), November (N) and December (D) of 2000. 


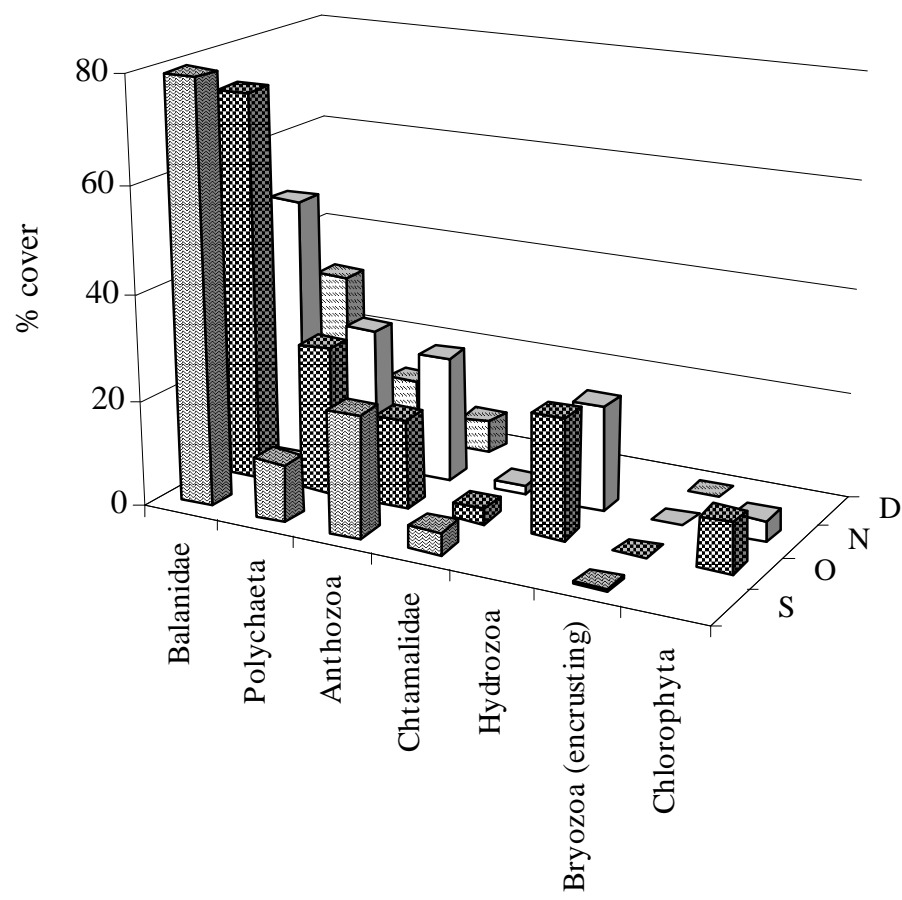

Figure 6 - Percent cover of the main groups in the monitoring treatment at Catalão, in September (S), October (O), November (N) and December (D) of 2000.

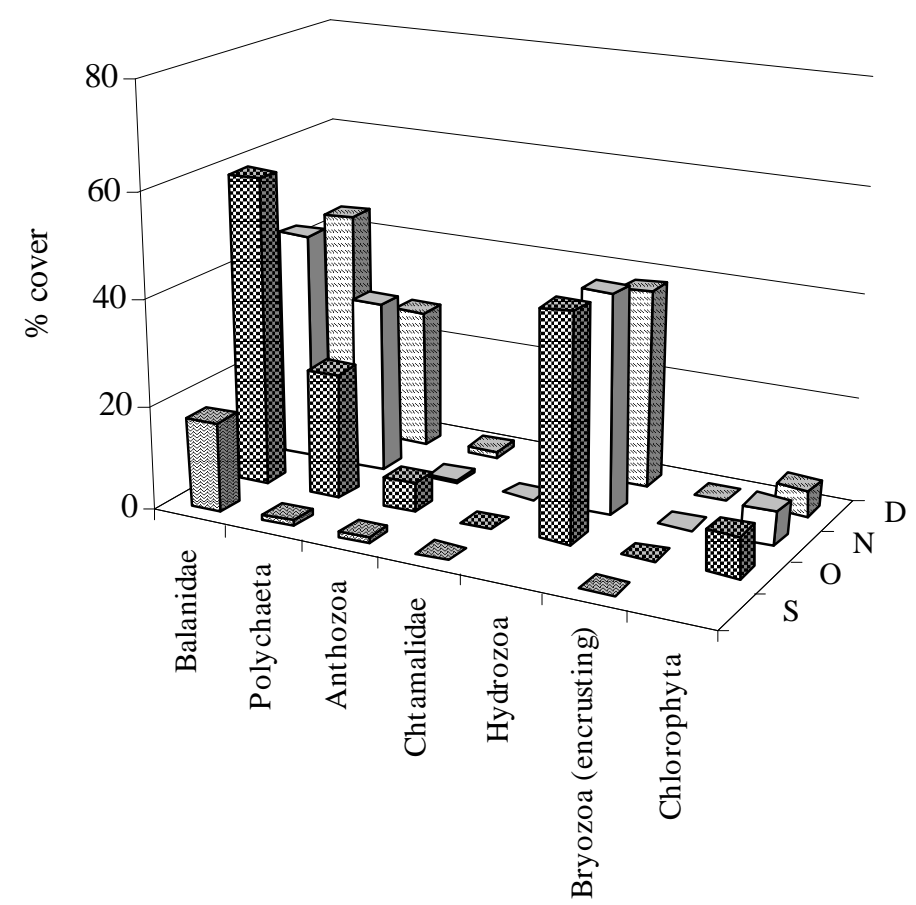

Figura 7 - Percent cover of the main groups in the recruitment treatment at Catalão, in September (S), October (O), November (N) and December (D) of 2000. 


\section{Community Structure}

At Urca, the community composition between the monitoring and the recruitment treatment presented a low similarity until the third month of the study. However, in the last month, the treatments were approximately $76 \%$ similar (Fig. 8). At Catalão, both treatments showed a similarity at $70 \%$ in

November, increasing to $80 \%$ in December (Fig. 9).

Cluster analysis with Bray-Curtis index showed that the recruitment and monitoring treatments formed two distinguished groups at Urca (Fig. 10). However, the recruitment transects over the months presented a lower similarity than the monitoring transects. At Catalão, in the second month, the similarity between the two treatments was approximately $72 \%$. In the following months, this similarity was even higher $(78 \%)$. These groups were formed, probably, due to the Balanidae family, which occurred at Catalão with a high percentage cover in both treatments (Fig. 11).

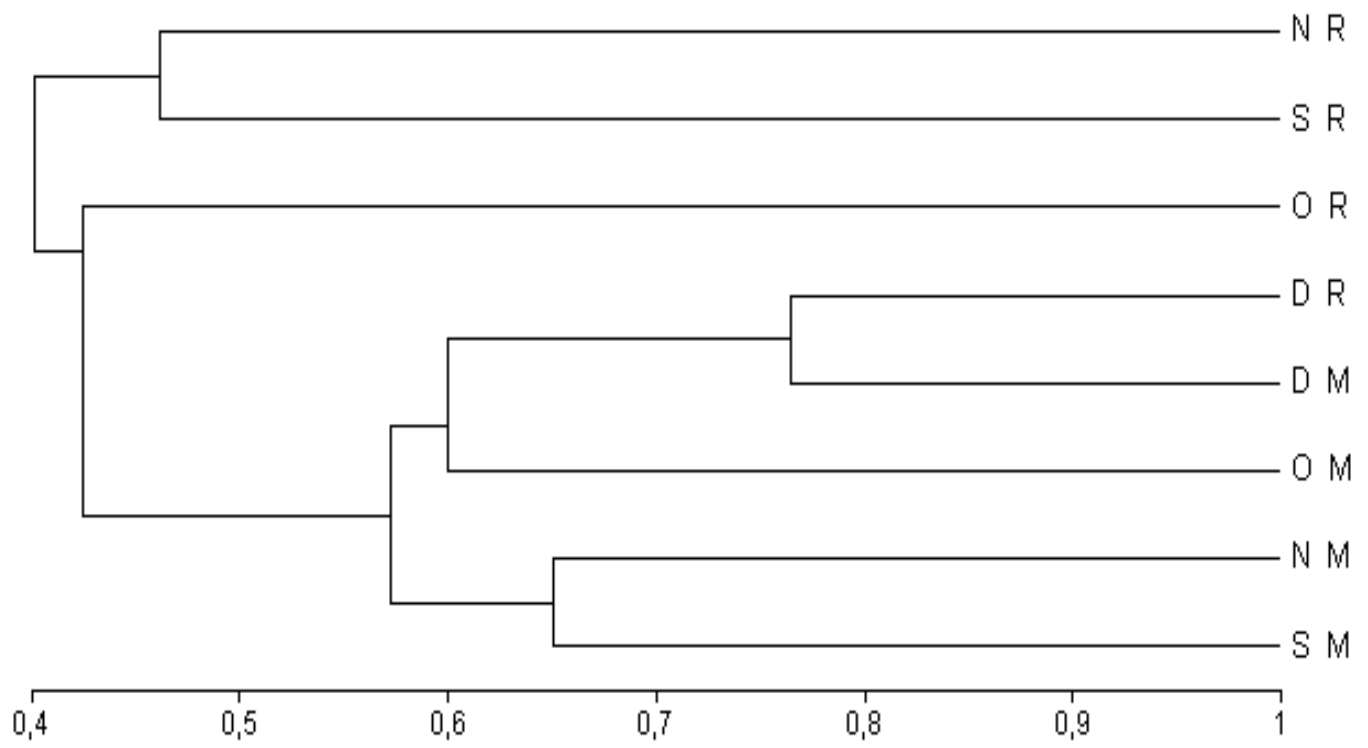

Figure 8 - Dendrogram with the binary index of Jaccard, with UPGMA aggregation algorithm with data from Urca. Monitoring (M) and Recruitment (R) treatments, in September $(\mathrm{S})$, October (O), November (N) and December (D) of 2000. 


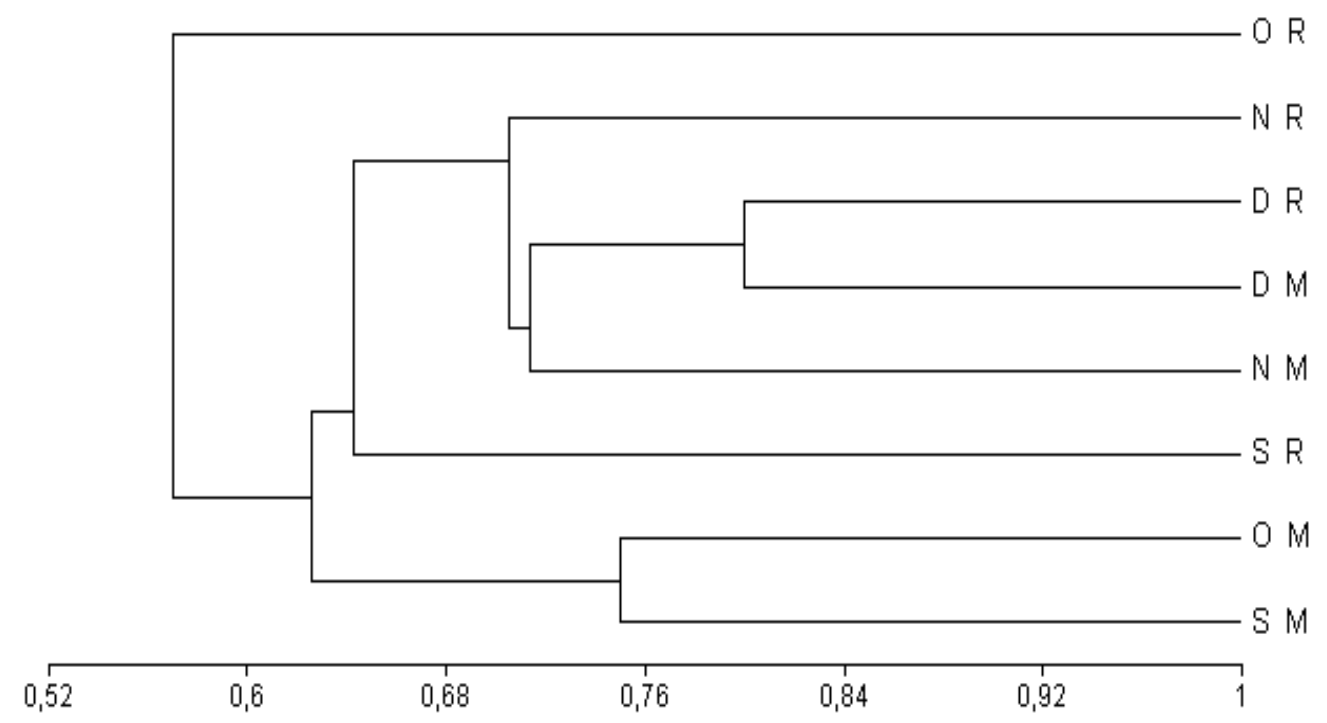

Figure 9 - Dendrogram with the binary index of Jaccard, with UPGMA aggregation algorithm with data from Catalão. Monitoring (M) and Recruitment (R) treatments, in September (S), October (O), November (N) and December (D) of 2000.

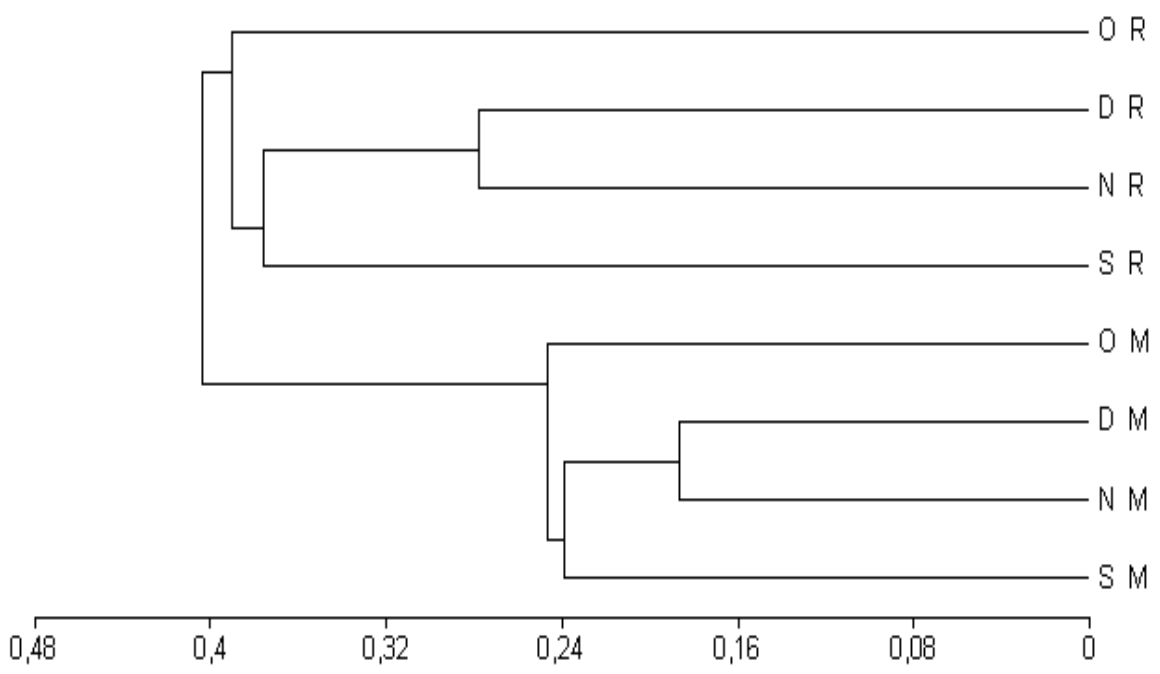

Figure 10 - Dendrogram with the quantitative index of Bray-Curtis, with UPGMA aggregation algorithm with data from Urca. Monitoring (M) and Recruitment (R) treatments, in September (S), October (O), November (N) and Dcember (D) of 2000. 


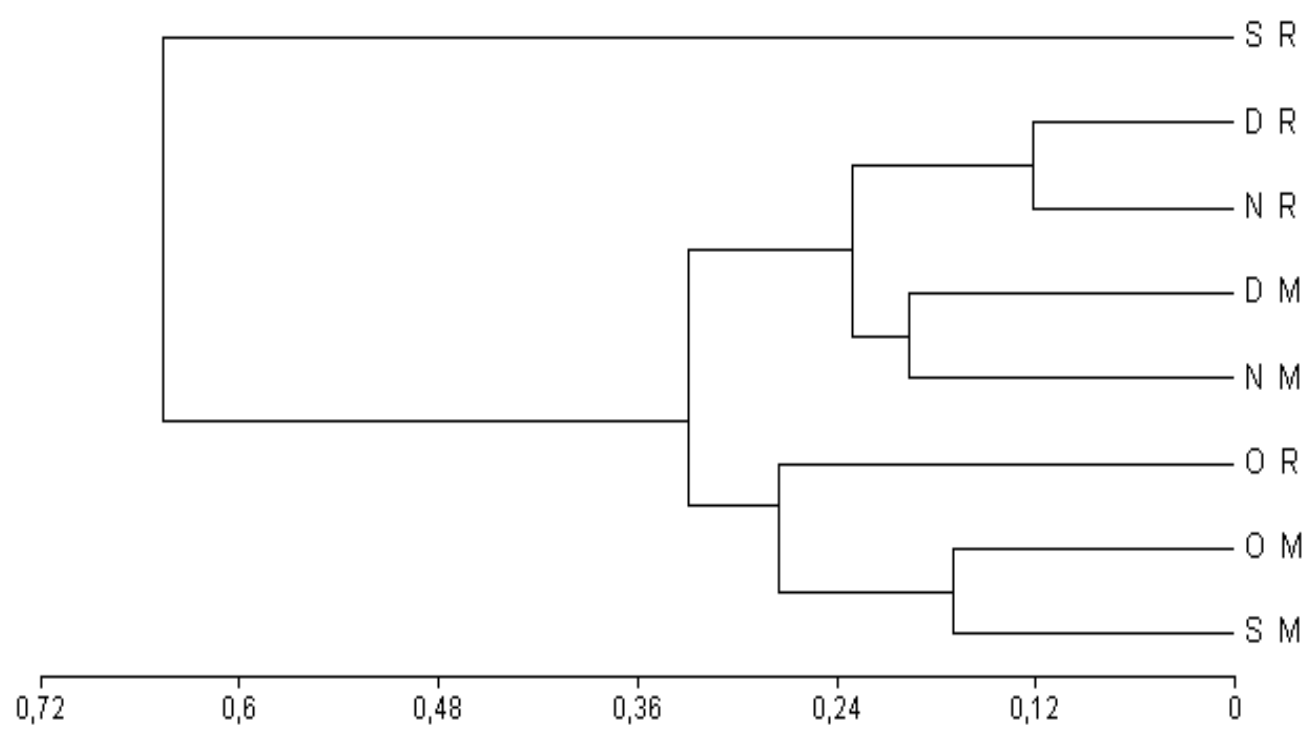

Figure 11 - Dendrogram with the quantitative index of Bray-Curtis, with UPGMA aggregation algorithm with data from Catalão. Monitoring (M) and Recruitment (R) treatments, in September (S), October (O), November (N) and December (D) of 2000.

\section{DISCUSSION}

The richness and abundance of taxa were different between the areas. These differences could be probably related to the pollution level in each area although other factors as salinity could also be related.

The total number of taxa was higher at Urca than at Catalão during the whole period of this study. The high species richness in the former site was expected because at moderate levels, organic pollution could increase biomass and even diversity of benthic communities (Silva et al., 1989). At higher levels, however, eutrophication causes a decrease in biomass and richness of species. This decrease of diversity may be caused by competitive exclusion between the tolerant species and the non-tolerant ones (Murray and Littler, 1978). Many studies have shown that in areas with low dissolved oxygen and high turbidity, the benthic communitites have a lower abundance, diversity and biomass (Rastetter and Cooke, 1979; González-Oreja and Saiz-Salinas, 1998).

The rate of substrate colonization by benthic communities was one of the main differences between the two studied areas. The development rate of communities was higher in eutrophicated areas than in the oligotrophic ones (Moran and Grant, 1989; Silva, 1998). In an experiment on algal succession in the intertidal zone at California (USA), Murray and Littler (1978) observed a full colonization of the substrata in an eutrophicated area in only one month. These authors also showed that in a non-polluted area, the substrate was not been entirely covered after a 30-month period. The development rate of benthic communities at Urca and Catalão could be related to the number and characteristics of species found in both areas. At Catalão, the higher rate of community development could be due to the presence of opportunistic species and its lower species richness when compared with Urca.

The high percent cover of the barnacle B.amphitrite at Catalão showed that this species was tolerant to polluted environments (Lacombe, 1977; Calcagno et al., 1998). Since this species was also found at Urca, but in a lower percent cover, it could be considered as a good organic pollution indicator.

Algae may also be used as pollution indicators. The high percent cover of the chlorophyte Ulva spp. in the first recruitment month at Urca showed the rapid colonization of the substrate by species of 
this genus. Genera such as Ulva and Enteromorpha were initial colonizers of clean substrates in eutrophicated areas (Murray and Littler, 1978). The low diversity of algae found at Catalão could be due to the high level of pollution and/or high water turbidity in this area. This factor causes a reduction of light, which affect the less tolerant species to high levels of turbidity.

Among polychaetes, the species Polydora websteri occurred in almost all months of the recruitment and monitoring treatments at Urca and Catalão. Gray (1981) suggested that species of this genus were opportunistic and tolerant to organic pollution.

Ascidians occurred only at Urca with low percent cover. This group is known to be tolerant to a variety of environmental conditions (Naranjo et al., 1996). Some species such as Styela plicata could be considered good indicators of stressed areas (Mayer-Pinto and Junqueira, 2003), whereas other species were considered sensitive to stress and could be used as negative pollution indicators. Sponges are considered good negative pollution indicators (Muricy, 1989; Carballo et al., 1996) and did not occur in the most impacted area. Hymeniacidon heliophila, however, occurred in both treatments at Urca in almost all months. Other species of sponges rarely occurred at that area. Sponges are not good colonizers, and usually appear later in the fouling development (Silva, 1998). In this study, sponges only occurred in the second month of the recruitment treatment.

The bryozoans occurred in both areas, but their species richness was higher at Urca. The hydrozoan Obelia dichotoma had a high percentage cover at Catalão (more eutrophicated), occurring in both treatments in almost all months, whereas at Urca, this species was found only in one month with a low percentage cover. This result suggested that this species was tolerant to organic pollution. Obelia dichotoma presented a rapid colonization in the recruitment treatment at Catalão, where it was found in the first month transects of this treatment. This indicated that this species was also a pioneering one in succession processes.

The relative abundance of organisms, the rate of community development and the recovering of community species composition seemed to be related mainly to the pollution level, although other factors could also be important. The faster community development and recovery at the most polluted area was probably related to the existence of simple and resilient communities in the more impacted area. The four-month period studied in this work was enough to detect spatial and temporal differences between the benthic communities in the two areas at Guanabara Bay.

\section{ACKNOWLEDGEMENTS}

We would like to thank Benthos Laboratory Team (UFRJ) for their assistance in the field work; Dr. Paulo César de Paiva (UFRJ) for polychaetes identification; Dr. Yocie Yoneshigue Valentin and Tiago Filgueiras Porto (UFRJ) for algae identification; M.Sc. Fernando Coreixas Morais (Museu Nacional - UFRJ) for Porifera identification; Dr. Rosana Moreira da Rocha (UFPR) for the ascidians identification and Mariana Mayer-Pinto for the english version.

\section{RESUMO}

O objetivo deste estudo foi descrever e comparar a sucessão das comunidades bentônicas da região entre-marés, em duas áreas na Baía de Guanabara, RJ, Brasil: Urca, uma área sujeita a moderado nível de poluição orgânica, e Catalão, uma área extremamente poluída. Em cada área, três transectos verticais foram raspados um mês antes do início do estudo, para se avaliar o recrutamento dos organismos (tratamento Recrutamento), enquanto três outros transectos foram monitorados sem manipulação (tratamento Monitoramento). A porcentagem de cobertura dos organismos foi avaliada pelo método de interseção. A composição específica e a abundância relativa dos organismos foram avaliadas mensalmente entre Setembro e Dezembro de 2000. Um total de 26 espécies foi encontrado na Urca, enquanto 13 foram encontradas no Catalão. Após quatro meses, a composição específica observada no recrutamento na Urca foi muito similar $(76 \%)$ a observada no monitoramento. No Catalão, três meses de estudo foram suficientes para alcançar $70 \%$ de similaridade, aumentando para $80 \%$ no quarto mês. A porcentagem de cobertura dos organismos mais abundantes na Urca, não foi similar entre os transectos do monitoramento e do recrutamento, após os quatro meses do estudo $(<40 \%)$, enquanto que no Catalão, a similaridade foi de $72 \%$ já no segundo mês. A comunidade encontrada na área 
com alto grau de poluição orgânica (Catalão) recuperou mais rapidamente do que a comunidade da área com moderada poluição orgânica (Urca). A maior velocidade de desenvolvimento e recuperação da comunidade bentônica da área com alta poluição orgânica em relação à área menos poluída, pode estar relacionada, principalmente, à existência de comunidades mais simples e resilientes na área mais degradada.

\section{REFERENCES}

Benedetti-Cecchi, L. (2000), Predicting direct and indirect interactions during succession in a midlittoral rocky shore assemblage. Ecol. Monogr., 70, 45-72.

Calcagno, J. A.; Gappa, J. L and Tablado, A. (1998), Population dynamics of the barnacle Balanus amphitrite in an intertidal area affected by sewage pollution. J. Crust. Biol., 12, 128-137.

Carballo, J. L.; Naranjo S. A. and Garcia-Gomez, J. C. (1996), Use of marine sponges as stress indicators in marine ecosystems at Algeciras Bay (southern Iberian Peninsula). Mar. Ecol. Prog. Ser., 135, 109-122.

Currie, D. R. and Parry, G. D. (1999), Changes to benthic communities over 20 years in Port Phillip Bay, Victoria, Australia. Mar. Poll.Bull., 38, 36-43.

Díez, I.; Secilla, A.; Santolaria, A. and Gorostiaga, J. M. (1999), Phytobenthic intertidal community structure along an environmental pollution gradient. Mar. Poll. Bull., 38, 463-472.

González-Oreja, J. A. and Saiz-Salinas, J. I. (1998), Exploring the relationships between abiotic variables and benthic community struture in a polluted estuarine system. Wat. Res., 32, 3799-3807.

Gray, J. S. (1981), The effects of pollution on benthic communities. In: Barnes, R. S.; Miller, P. L. and Paul, J. (Eds.). Ecology of marine sediments: an introduction to the structure and function of benthic communities. Cambridge: Cambridge University Press, pp. 88-104.

Gray, J. S. and Christie, H. (1983), Predicting long-term changes in marine benthic communities. Mar. Ecol. Prog. Ser., 13, 87-94.

Holland, D. L.; Crisp, D. J.; Huxley, R. and Sisson, J. (1984), Influence of oil shale on intertidal organisms: effect of oil shale extract on settlement of the barnacle Balanus balanoides (L.). J. Exp. Mar. Biol. Ecol., 75, 245-255.

Kjerfve, B.; Ribeiro, C. H. A.; Dias, G. T. M.; Filippo, A. M. and Quaresma, V. S. (1997), Oceanographic characteristic of an impacted coastal bay: Baía de Guanabara, Rio de Janeiro, Brasil. Contin. Shelf Res., 17, 1609-1643.
Lacombe, D. (1977), Anatomia e microanatomia de Balanidae da Baía de Guanabara (Crustacea, Cirripedia). Rev. Brasil. Biol., 37, 151-165.

Machado, K. R. S. S.; Chapman, A. R. O. and Coutinho, R. (1992), Patch structure in a tropical rocky shore community in Brazil: a mosaic of successional states? Ophelia, 35, 187-195.

Mayer-Pinto, M. and Junqueira, A. O. R. (2003), Effects of organic pollution on initial development of fouling communities in a tropical bay, Brazil. Mar. Pol. Bull., 46, 1495-1503.

Mccook, L. J. and Chapman, A. R. O. (1997), Patterns and variations in natural succession following massive ice-scour of a rocky intertidal seashore. J. Exp. Mar. Biol. Ecol., 214, 121-147.

Moran, P. J. and Grant, T. R. (1989), The effects of industrial pollution on the development and succession of marine fouling communities. I. Analysis of species richness and frequency data. Mar. Ecol., 10, 247-261.

Muricy, G. (1989), Sponges as pollution-biomonitors at Arraial do Cabo, southeastern Brazil. Rev. Brasil. Biol., 49, 347-354.

Murray, S. and Littler, M. (1978), Patterns of algal sucession in a perturbated marine intertidal community. J. Phycol., 14, 506-512.

Naranjo, S. A.; Carballo, J. L. and Garcia-Gomez, J. C. (1996), Effects of environmental stress on ascidian populations in Algeciras Bay (southern Spain). possible marine bioindicators? Mar.Ecol..Prog. Ser., 144, 119-131.

Necchi-Júnior, O.; Branco, H. Z. and Dip, M. R. (1994), Use of macroalgae for the evaluation of organic pollution in the Preto River, northwest of São Paulo State. An. Acad. Bras. Ciên., 66, 359-371.

Omena, E. P.; Zalmon, I. R. and Barreto, C. C. (1993), Fouling community of Urca Beach, Guanabara Bay (RJ), Brazil: a descriptive approach. Ac.Biol. Leop., 15, 37-50.

Rastetter, E. B. and Cooke, W. J. (1979), Responses of marine fouling to sewage abatement in Kaneohe Bay, Oahu, Hawaii. Mar.Biol., 53, 271-280.

Saiz-Salinas, J. I. and Urkiaga-Alberdi, J. (1999), Faunal responses to turbidity in a man-modified bay (Bilbao, Spain). Mar. Environ. Res., 47, 331-347.

Scheer, B. T. (1945), The development of marine fouling communities. Biol. Bull., 89, 103-121.

Silva, S. H. G.; Junqueira, A. O. R.; Martins-Silva, M. J.; Zalmon, I. R. and Lavrado, H. P. (1989), Fouling and wood-boring communities distribuition on the coast of Rio de Janeiro, Brazil. In: Neves, C. and Magoon, O. T. (Eds.). Coastlines of Brazil. New York: American Society of Civil Engineers. pp. 95-109.

Silva, T. A. (1998), Efeitos da eutrofização sobre as comunidades incrustantes em Angra dos Reis. Dissertação (Mestrado), Universidade Federal do Rio de Janeiro, Rio de Janeiro, Brasil. 
Sousa, W. P. (1979), Experimental investigations of disturbance and ecological sucession in a rocky intertidal algal community. Ecol. Monogr., 49, 227-254.

Sutherland, J. P. (1974), Multiple stable points in natural communities. Am. Nat., 108, 859-873.

Whoi (1952), Temporal sequences and biotic successions. In: Mmarine fouling and its prevention. Woods Hole Oceanographic Institution. United States Naval Institute. Annapolis, Maryland. pp. 42-47.

Zar, J. H. (1996), Biostatistical analysis. New Jersey: Prentice-Hall Inc.

Received: June 18, 2004 Revised: October 19, 2004; Accepted: May 20, 2005 . 